\title{
Conceptualizing sustainable development and global supply chains
}

\author{
Frank Boons ${ }^{\mathrm{a}, *}$, Henrikke Baumann ${ }^{\mathrm{b}}$, Jeremy Hall ${ }^{\mathrm{c}}$ \\ a Department of Public Administration, Erasmus University Rotterdam, The Netherlands \\ ${ }^{\mathrm{b}}$ Environmental Systems Analysis, Chalmers University of Technology, Göteborg, Sweden \\ c Faculty of Business Administration, Simon Fraser University, Burnaby, Canada
}

\section{A R T I C L E I N F O}

Available online 29 June 2012

\begin{abstract}
A B S T R A C T
This paper introduces a holistic approach to the study of sustainable development of global product chains. We first present a number of perspectives on this topic from disciplines such as economic geography, management science, sociology and environmental sciences. Each of these approaches brings in a specific focus: the consequences of geographical dispersion of economic activities, measurement of ecological and social impact, managing sustainability in supply chains, and power asymmetry among economic actors. Until now, these disciplinary research lines have remained unconnected. We argue that ecological economics provides a promising background for a more holistic conceptualization. To this end, we formulate five basic questions that serve to advance the study of sustainability throughout the product chain by connecting the foci of the identified scientific disciplines. The aim of advancing a holistic perspective has guided the selection of papers for this special subsection, which are introduced throughout the text.
\end{abstract}

(c) 2012 Elsevier B.V. All rights reserved.

\section{Introduction}

This paper discusses recent theoretical approaches for conceptualizing sustainable development in global supply chains. Increasing the sustainability of production and consumption activities requires that we ground our managerial and policy actions on an analysis of economic systems beyond individual firms and consumers. In the past, the product chain has been recognized as a powerful unit of analysis (Boons and Wagner, 2009), where the product life cycle delineates a meaningful system for assessing the environmental impact of economic activities by facilitating an integrated assessment of various environmental impacts across related economic stages of production, consumption, recycling, and waste handling. For example, the development of product life cycle assessment (LCA) since the 1990s makes clear how attempts to reduce ecological impact in one part of the chain affect other parts of the chain (Aurich et al., 2004; Brunklaus et al., 2010; Hunt and Franklin, 1996; Matos and Hall, 2007; Matsuhashi et al., 2000), illuminating the interconnectedness of policy and management decisions and their ecological consequences (Baumann and Tillman, 2004). The product chain perspective thus combines pressures for efficiencies from an economic and ecological perspective.

The application of the product life cycle analytical point of view in policy and practice is complicated by the fact that the activities that constitute a product chain are performed by economic actors

\footnotetext{
* Corresponding author.

E-mail address: boons@fsw.eur.nl (F. Boons).
}

embedded in networks of relationships that are increasingly global. Global product chains can be seen as networks through which environmental and social impacts are transferred across boundaries (Cave and Blomquist 2008; Dahlström and Ekins 2006). The product chain system boundary thus enables the analysis of important shifts that have taken place in socio-economic systems, such as the move of production activities towards emerging economies such as China.

The networks that make up product chains involve firms and consumers, but also the governmental agencies and NGOs that seek to shape the choices made by firms. All these relationships affect the operational and strategic choices made by firms as well as consumer practices. As a result, they also affect the environmental and social impact throughout the product life cycle. As far as policies for sustainable development are concerned, researchers, policymakers and practitioners have discovered that the linkages between economic actors that are associated with the production and consumption of a specific (set of) products form powerful conduits through which sustainability efforts can be developed and disseminated.

Unfortunately, a holistic understanding of sustainability in relation to product chains continues to be hampered by imperfect linkages across a number of research communities that have taken up this issue. The ways in which firms deal with the negative impact of their activities on societies and natural ecosystems is gaining hold as a topic of research in management and organization studies (Bansal and Gao 2006), innovation studies (Weber and Hemmelskamp 2005) and economic geography (Deutz and Gibbs 2008; Dicken, 1994) among others. However, to a considerable extent these insights have been developing in isolation, and have not received substantial attention within the field of ecological economics. 
In this paper, we discuss various theoretical lenses under which the sustainability of product chains has been analysed. Consistent with Ecological Economics' focus of addressing the relationships between natural ecosystems and economic systems in the broadest sense, and thus from a holistic perspective (Costanza, 1989), the sustainable global value chain literature makes use of various theoretical approaches, resulting in a truly trans-disciplinary discourse. ${ }^{1}$ Ecological Economics thus constitutes a promising lens to analyse the sustainable development of production and consumption activities, but to date there have been relatively few papers published in the Journal. Indeed, an investigation using Google Scholar found that out of the 100 most cited papers on the sustainability of product chains, only three were published in Ecological Economics (see the bar graph in Fig. 1: Distribution of 100 most cited articles on "sustainable "product chains"' in scholarly journals (Google Scholar, as of April 5, 2012). Thus, while the topic of sustainable supply/global value chain discourse fits well within Ecological Economics' emphasis on trans-disciplinary and problem-focused research, much of the theoretical discourse has been spread over many research communities, with relatively little overlap among them, resulting in a highly fragmented discourse lacking a common theoretical language. The purpose of this paper and special subsection is thus to rectify this problem by drawing together contributions from different perspectives as an ecology of ideas (Bateson 1972; Toulmin 1972). While firmly based in the literatures produced by these communities, we do not aim to provide a full literature review. Instead, we present leading ideas to capture the diversity of insights and their potential for crossfertilization.

We begin with a characterization of research based on disciplinary boundaries, as we find these to be still important in setting boundaries for research communities (Section 2), and discuss how various disciplines have been used to investigate the problem under study. We then move on to develop a holistic interpretation by drawing together insights under a number of core questions worthy of further research (Section 3).

\section{Theoretical Lenses on Sustainability in Global Product Chains}

\subsection{A Note on Concepts}

Providing an overview of the insights that have emerged on product chains in different disciplines is hampered somewhat by the use of different concepts to signify the object of study. We are sensitive to these differences, as concepts can be considered to be small pieces of theory (Stinchcombe 1968). The differences therefore indicate the specific foci of disciplines. In developing this overview we have worked with an inclusive definition of product chains: the networks of actors that are involved in production and consumption activities related to a product and who create and transform geographically dispersed flows of materials and energy leading to social and ecological impacts, some of which are perceived as problematic. This definition is intended to include dimensions and aspects that are highlighted by concepts from various disciplines:

- the inter-organizational dimension that has been stressed by several authors using the product chain concept (Boons, 2002, 2009; Iansiti and Levien, 2004; Matos and Hall, 2007);

- the management of supply chains (Goldbach et al., 2003; Hall, 2000, 2001; Seuring and Müller, 2008);

\footnotetext{
${ }^{1}$ We use the label trans-disciplinary to denote research that aims to contribute to the solution of complex and multidimensional problems, and which draws on insights from different disciplines to develop a more holistic perspective (Wickson et al., 2006). This fits with the agenda of ecological economics.
}

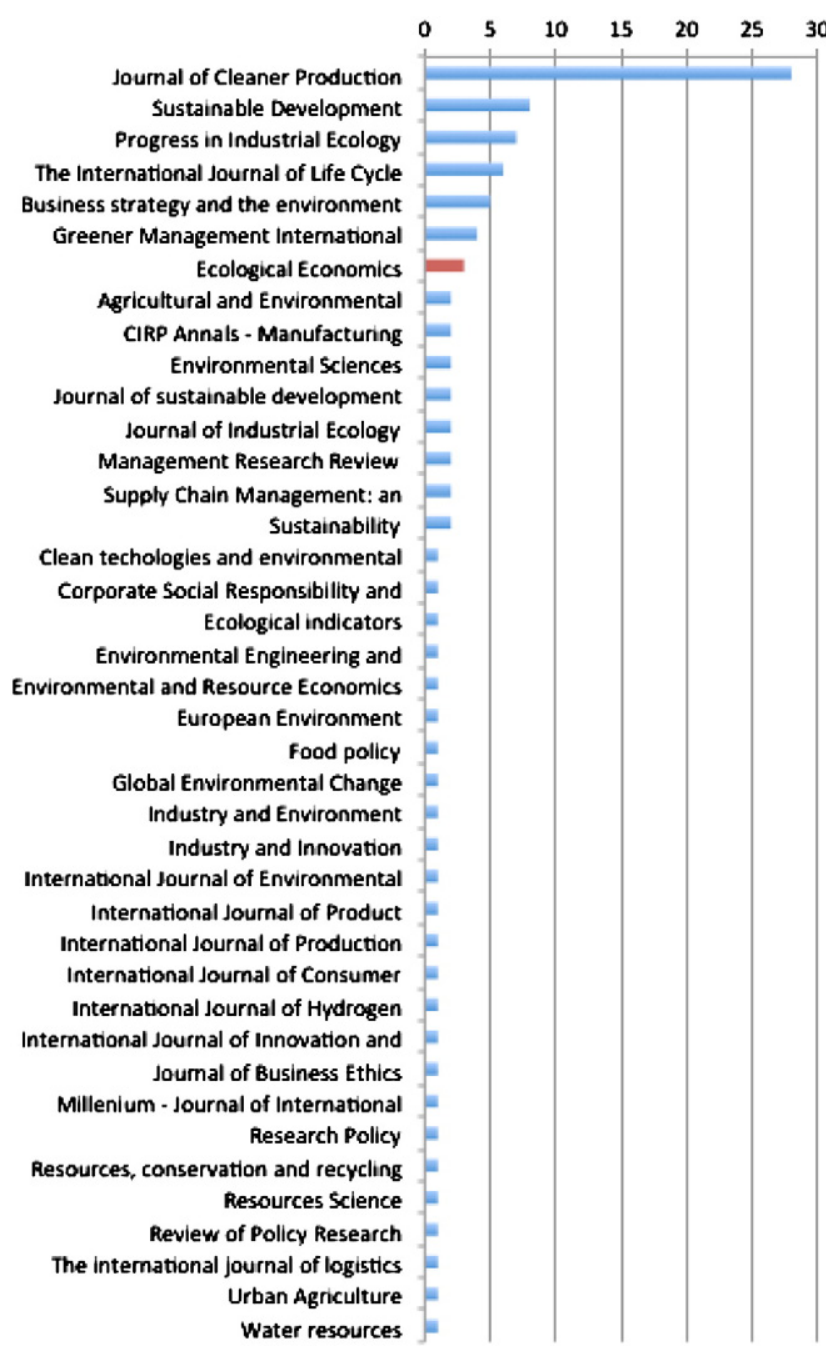

Fig. 1.

- a recognition that the analysis of production activities needs to be complemented with that of consumption (Green et al., 2000; Hertwich, 2005; Spaargaren, 2003);

- innovation systems, a concept that stresses that the development of new products also involves social networks (Boons, 2009; Hall, 2000; Oltra and Saint Jean 2009; Weber and Hemmelskamp);

- the environmental dimensions, described with life cycle assessment (Baumann and Tillman, 2004; Guinée, 2002; Matos and Hall, 2007; SETAC, 1993);

- the structure of the 'life cycle', which is the core of LCA, has also been suggested for structuring other methods of analysis, e.g. in economic materials-product chain modeling (Schwarz, 2006) and life cycle costing (Steen, 2005), and introduced into triple-bottomline accounting (Foran et al., 2005). Also social assessment methods for product chains have been put forward, e.g. social LCA (UNEP, 2009).

We discuss these dimensions within the context of five perspectives: economics and management science; sociology and organizational science; governance studies; economic geography; and environmental systems engineering. We acknowledge that these perspectives do not fully capture all of the theoretical diversity that has been used to explore the topic, but they are sufficient as a starting point for illustrating the main ideas and insights for potential crossfertilization. 


\subsection{Economics and Management Science}

Although the underlying concepts of both global supply chains and sustainable development are influenced by mainstream economics, economics journals such as the Journal of Political Economy, American Economic Review and Econometrica have not published any studies on the topic. However, a plethora of publications in more specialized journals concerned with for example operations and production management, economic geography, supply chain management, marketing and environmental management have drawn on a number of economics theories.

Perhaps the most influential in the field of business administration is transaction cost economics (TCE), initially pioneered by Coase (1937) and later Williamson $(1975 ; 1985)$ that has provided insights in how and why sustainable supply chains develop (e.g. Carter and Rogers, 2008; Hall, 2000, 2001; Meisner Rosen et al., 2000; Tate et al., 2011). The primary focus for the "make or buy" decision is to minimize production ("make") and transaction ("buy") costs (Williamson, 1975), which in turn are shaped by asset specificity, purchasing frequency and uncertainty in the form of shirking (Williamson, 1985). According to Connelly et al. (2011), the TCE perspective suggests that firms base their decisions about sustainability practices primarily on the economic merits of the market versus hierarchy costs associated with those practices; firms will likely engage in sustainable marketing and/or the development of new eco-products when the economic rationale for doing so is clear. Drawing on transaction cost economics, Delmas and Montiel (2009) predict that "firms engaged in transactions involving high specific investments, and therefore greater dependency on their current customers than firms with lower asset specificity, are more likely to adopt ISO 14001" (p 178). Tate et al. (2011) found that suppliers are more likely to adopt environmental practices if information seeking, bargaining, and enforcement costs are minimized, especially if they believe the buyer-supplier relationship is on-going. However, the benefits from adoption must outweigh the costs associated with these practices, including the potential cost of lost business. Hall et al. (2009), Hall and Matos (2010) found that including socially disadvantages segments of society within the supply chain exacerbates transaction costs due to their geographically dispersed, small-scale production and due to a lack of understanding of basic technical and business knowledge; transaction cost economics approaches may thus discourage the inclusion of social parameters.

According to Connelly et al. (2011), while transaction cost economics may provide insights on how to economic decision making is formulated, it under-emphasizes environmental and social issues. Hall (2000) argues that, while transaction cost economics is a useful theoretical starting point, it does not fully describe innovation dynamics within the supply chain, but rather focuses on cost reduction in relatively stable supplier relationships. Indeed, while TCE has been widely used as a starting point for understanding sustainable supply chains, it is rarely used alone. For example, Carter and Rogers (2008) combine it with resource dependence theory, population ecology and the resource-based view of the firm, whereas Delmas and Montiel (2009) combine it with information economics and Tate et al. (2011) with institutional theory.

Another economic theory used to analyse sustainable global value chains (albeit applied more in the management literature than economics), is Porter's (1980) value chain analysis, a method of analysing how value is added in different coordinated activities (Carter and Rogers, 2008; Porter and Kramer, 2006). For example, Rieple and Singh (2010) examined the production chain of certified organic cotton and related products to understand where value is added in each category, and how it differs from traditional products. However, the majority of value chain studies concerned with social and environmental impacts have been studied under the area of economic geography, which is discussed below. There, the efficiency focus of economics is complemented with for example power dependency, a topic studied within the fields of sociology and organizational science, which we turn to next.

\subsection{Sociology and Organizational Science}

In contrast to the focus on efficiencies in economics, a sociological perspective on product chains takes as a starting point that such chains are constituted by organizations that are interrelated. The distinct field of organizational sociology emerged with a focus on intra-organizational phenomena, but since the 1970s the study of inter-organizational relations started to develop, first in terms of bilateral relations (Evan, 1966; Pfeffer and Salancik, 1978) and later, networks of organizations. In terms of theoretical contributions, we present the main thrust of three frequently used perspectives: resource dependency theory, organizational institutionalism, and business ecosystems.

Resource dependency theory was developed in the 1970s by Pfeffer and Salancik, 1978. It starts from the observation that no organization can fulfil its goals without obtaining resources from its environment. As these resources are controlled by other organizations, (asymmetric) dependency relations exist between organizations. Dependency is high when a resource is central to the focal organization and cannot easily be replaced (for instance through accessing it from another supplier). Resource dependency builds on the assumption that organizations will manage such relationships to achieve maximum autonomy. When dependency is low, transactions can be coordinated through the market mechanism, while in relationships where the firm is highly dependent, it will engage in more intensive coordination mechanisms such as joint ventures, partnerships, or even resort to vertical integration. Thus, power asymmetries rather than efficiency considerations (as in the case of TCE discussed above) are taken to be central in determining types of coordination mechanisms.

Resource dependency theory is useful because it enables the analysis of power due to asymmetric dependency among firms. Such power issues are intrinsic to supply chains, and they affect how issues of sustainability can be transmitted from one firm to another (Hall, $2000,2001)$. Power has been used within the supply chain and marketing literature under the term 'channel power', as the ability of one channel member (i.e. a firm within a supply chain) to control the decisions of another (El-Ansary and Stern, 1972). Channel leaders can "...influence the marketing policies and strategies of other channel members for the purpose of controlling various aspects of channel operations" (Price, 1995: 262), and is analogous to the "focal company' used by Seuring and Müller (2008) within the sustainable supply chain literature. Within the marketing literature, channel power has been measured by, for example, the percentage of the channel member's business activities with the other firm, the contribution towards profits attributed from the relationship and the commitment of one firm's marketing policies towards another. Within the industrial organizational literature, the division of profits is typically used to assess market power, which in turn is shaped by monopoly power derived for example through industry concentration, such as many manufacturers being dependent on only a few retailers (Ailawadi et al., 1995). Porter (1980) argues that intrinsic buying power is based on the volume of purchasing, the number of alternative sources, the level of transaction and or negotiating costs, the threat of backward integration and the fixed costs of switching suppliers.

The relevance of the resource dependency perspective becomes even more apparent when resources are taken to include not only finances and physical inputs for production, but also knowledge and legitimacy. The acquisition of the latter may be viewed as a resource (Dowling and Pfeffer, 1975) and can be defined as the situation in which the activities of a firm 'are desirable, proper, or appropriate within some socially constructed system of norms, values, beliefs, and definitions' (Suchman 1995: 574). Legitimacy is acquired and maintained by firms through interactions with governmental agencies and other organizations that formulate and monitor formal 
rules, as well as NGOs and the media who are able to influence the legitimacy of an organization through influencing public perceptions (Oliver 1991). Legitimacy is also a source of power (French and Raven, 1959), where, for example, one supply chain member has the perception that another has the legitimate right to prescribe behavior. Hall (2000) argued that increased pressure on large supply chain channel leaders from, for example, NGOs and consumers legitimized their efforts to coerce suppliers into reducing their environmental impacts, especially smaller, lower profile firms that would otherwise not do so.

Resource dependency is often framed in terms of a focal organization and its bilateral relationships (Evan, 1966). For the analysis of product chains the firm is better viewed as being part of resource networks (Boons, 2009). The firm interacts with other firms and stakeholders, and these often are related to one another, or to still other organizations (Harland, 1996; Rowley, 1997). In extending their sustainability efforts beyond the organizational boundary, firms engage in relationships with other organizations that include not only supplying firms, but also competitors, NGOs, governmental agencies, and knowledge institutes. Thus, firms that seek to further sustainability in product chains operate in resource networks to acquire material and financial resources, knowledge, and legitimacy (Boons, 2009). Note however that dependency can change over time. A case study by Goldbach et al. (2003) provides insights into the way in which an effort to 'green the supply chain' by a large retailer first results in increased dependency, as assessment criteria are developed and suppliers are trained to adhere to them; when supply networks are instituted, over time dependency decreases and the relationships develop towards market-based exchanges.

The resource dependency perspective can be complemented by that of organizational institutionalism, a theory that seeks to explain why organizations in certain fields have a tendency to become more alike over time. It builds on the assumptions that organizations, in order to survive, need to obtain legitimacy, a 'license to operate'. In that quest, collectively they may show isomorphic tendencies due to three mechanisms: coercion, mimicry and normative isomorphism (Dimaggio and Powell, 1983). Coercion can originate from governmental rules, but also from powerful organizations in the field that set standards that others have to follow. Mimicry is hypothesized to occur when there is uncertainty about the relationship between actions and results; organizations will then imitate a peer that is seen as central. Normative isomorphism occurs through professionalization, where the acquired skills and knowledge of professionals is brought into different organizations.

By looking at the interplay between these mechanisms, institutionalism is relevant as it provides insight into the mechanisms that may cause sustainability efforts to spread throughout industry sectors (Hoffman 1997) as well as (parts of) a product chain (Boons, 2009; Manning et al. in this special issue).

A third contribution from organizational theory builds on a biological metaphor. It conceptualizes product chains as ecosystems, and through the application of distinct ecological metaphors, an analysis is made of the system as a whole and the role of firms in it (Moore, 1993). Iansiti and Levien (2004) build on the concept of a keystone species, a species whose removal from an ecosystem results in a collapse. Others have used the ecosystem metaphor in a more generic way. Also, some use it to denote the resource networks around a single firm (as in 'the Microsoft ecosystem'). In that way, competitive positions can be compared in terms of the wider system in which they are embedded. In both cases, looking at product chains in terms of ecosystems provides insight into the way in which addressing sustainability concerns involves a wider set of actors engaged in complex relations (Ramachandran, 2012).

\subsection{Governance Studies}

When actors have the intention to increase the sustainability of a product chain, they engage in the coordination of a diverse set of actors to address collective issues. Such coordination constitutes the research subject of governance, which is studied by members of the public and business administration fields. As product chains often extend beyond national boundaries, and are mainly driven by the choices and activities of private actors (ranging from subsistence farmers to multinational firms), the product chain system boundary implies that national governmental policy by itself may not be effective in achieving such coordination, even if it focuses specifically on products (Rubik, 2006). This policy area thus shows a great reliance on private actors and market mechanisms; much of the tools used by government can be seen as seeking to nudge the market process in a different direction, as in the case of eco-labeling. Alternatively, private actors engage in arrangements that are characterized as selfgovernance. They set up standards that reflect some level of sustainability, and find ways to monitor each other's behavior, as in the case of the Marine Stewardship Council (Lozanoa et al., 2010; Schouten and Glasbergen, 2011). The constitution of such arrangements of self-governance can start as the initiative of one firm that seeks to make its supply chain more sustainable; given certain market characteristics, the firm may have an incentive to include its competitors, making the initiative into an independent standard organization, as in the case of Utz Certified Coffee (Boons, 2009). Alternatively, a standard may be a collective initiative from the start. Such arrangements are difficult to bring about, given the multiplicity of interests and definitions of sustainability that actors bring to the table (Boons and Mendoza, 2010).

In several product chains, self-governance through standards has led to the emergence of multiple standards, as is the case in the coffee market (Kolk, 2005). This has raised questions about their different interpretations of sustainability. Manning et al. (2012-this issue) analyse how multiple sustainability standards co-evolve over time at the global level, and discuss the possibility that different levels of sustainability may be useful in allowing producers to move towards sustainability one step at a time. While firms are thus prime movers in the governance of sustainability in product chains, governments still play a role, as analysed by Vermeulen and Kok (2012-this issue).

\subsection{Economic Geography}

Product chains have received considerable attention from economic geographers under the label of commodity chain analysis. This concept draws on the efficiencies focus in economics as well as concepts derived from sociology and organization theory, such as governance and power dependency (Gereffi, 1999, 2001; Gereffi and Korzeniewicz, 1994; Giuliani and Bell, 2005; Humphrey and Schmitz, 2002; Kaplinsky 2000; Morrison et al., 2008). The term commodity chain analysis is derived from the study of world systems (Hopkins and Wallerstein, 1977), which studies the way in which periphery and center are connected at the global level. Additionally, this perspective focuses on the spatial distribution of power in relation to the production and consumption of commodities, suggesting that participation in global value chains can promote economic development through 'upgrading' firms' capacities to innovate by learning through for example exporting, foreign direct investment and spillovers, thus increasing their value-adding activities. Giuliani et al. (2005) argue that such perspectives are an effective alternative to improving productivity by 'squeezing' wages and profits, a common approach in developing countries. With the increased global dispersion of activities of specific product chain (Dicken, 1994), and the emergence of China as the 'production plant of the world', an investigation of the way in which global economic transactions translate into social and ecological impact is of increased relevance.

The original empirical studies on commodity chains revealed two basic patterns of power distribution. Producer-driven product chains (automobiles, computers), are vertical networks of production and distribution coordinated by large transnational firms. Buyer-driven 
product chains (food products, apparel, toys) are led by large retailers, marketers and branded manufacturers that coordinate the development of decentralized production networks in developing countries based on market exchanges rather than direct coordination. This dichotomy has been criticized as overly simplistic (Gellert, 2003); while highlighting important international dynamics, the commodity chain perspective ignores the relevance of national influences on firms. It has become clear that the relative importance of international links or national influence is an empirical variable (Boons, 2009; Dicken, 1994). Nevertheless, the commodity chain approach is valuable in providing a proven methodology to study the social dimension of product chains, also in relation to ecological impact and sustainability.

In response to criticism, Gereffi et al. (2005) have extended the commodity chain framework into Global Value Chain Analysis. Most global value chain studies deal primarily with social rather than environmental improvements, although it has been applied to supply chains for more sustainable biofuels (Hall et al., 2011) and tourism (Hall et al., 2012). These studies however recognize the limitations of the global value chain discourse, particularly the lack of consideration for unintended and detrimental consequences of technological development, which can lead to more harm than good, especially when there is a large variance in poverty and education levels among value chain participants. To compensate for these limitations, Hall et al. (2011) complement the global value chain perspective by combining it with evolutionary economics (Nelson and Winter, 1982), philosophy of science (Kuhn, 1962; Popper, 1945, 1959) and Aldrich and Fiol's (1994) concept of cognitive versus socio-political legitimacy; Hall et al. (2012) combine it with Baumol's (1990) typology of entrepreneurial outcomes (socially beneficial productive entrepreneurship, versus socially detrimental unproductive (rent seeking) and destructive (i.e. criminal) entrepreneurship, the emerging Base of the Pyramid (BOP) discourse (London and Hart, 2004; Prahalad, 2007), entrepreneurial alertness (Kirzner, 1973) and mindfulness (Langer, 1989). Thus, similar to the theories discussed above, the global value chain perspective needs to be combined with other theories to explain sustainable supply chain dynamics.

\subsection{Environmental Systems Engineering and Life Cycle Assessment}

Environmental studies of product systems can be traced back to the early 1970s, and have developed mainly from the environmental and engineering sciences. By now, there is a formalized methodology focusing on the physical flows throughout industry and society related to a product, from raw materials extraction, through production and use, to disposal: life cycle assessment (LCA). Environmental systems engineering has produced several other methods for flow modeling, but only LCA deals with the physical flows of a product chain. As a field, it has developed relatively independently from the social sciences, but some 'subjective' elements have been integrated into, for example, life cycle impact assessment methodologies for the relative weighting of different environmental problems. Similar to economics, the focus in LCAs can be on efficiency, albeit primarily ecological efficiencies rather than purely economic. Otherwise, LCAs are often used to identify where in the product chain the environmental risks, or 'hot spots', are; to better avoid shifting of environmental problems from one part of the chain to another; and to evaluate the significance of one environmental problem relative to another, e.g. global warming vs. eutrophication (Frankl and Rubik, 2000).

LCA is a methodology with many applications (e.g. eco-labeling, ecodesign, cleaner production), and many of the methodological choices depend on the purpose and the type of LCA study. For example, a change-oriented prospective study for cleaner production assessment comparing options for the production of a product requires a different type of modeling and data than the corresponding accounting study for eco-labeling of that type of product.

The LCA discourse has a dedicated journal, the International Journal of Life Cycle Assessment, although many LCA studies have also been published in more general environment journals such as Environmental Science and Technology, Journal of Cleaner Production and Journal of Industrial Ecology. The early development of the field focused on developing some kind of consensus around the methodology. This led to an international ISO standard, the ISO14040 series that in parts allowed for methodological alternatives in life cycle modeling. Two areas where the debate around these alternatives has been intense concern how the division of interconnected product systems should be made, and how to conduct impact assessment (Baumann and Tillman, 2004; Guinée, 2002). Methodological alternatives exist for several reasons:

- the need to adapt LCA to different purposes;

- the difficulty in describing certain issues, such as land use;

- the fact that certain methodological decisions are not value free, and are made differently in various social contexts. One example is how to allocate impacts, i.e. the partitioning of interconnected product systems and relative weighting of different environmental problems.

Although there are rules that specify what type of LCA should be used in a specific context, the diversity of methodological alternatives has often been taken for methodological flexibility that can be used for producing 'desirable' results, rather than one stemming from the modeling needs of different types of LCA studies and of different social perspectives on relationships in product systems. This diversity poses special problems for the ISO standard on LCA, since it aims to be a comprehensive standard for all types of LCA.

There is increasing insight in the causes of diversity of LCA studies. The comparative studies of Ekvall $(1992,1999)$ concluded that the purpose of a particular study, more than the product itself, governed methodological choices. In another comparison, Teehan and Kandlikar (2012) analysed LCAs of desktop computers, concluding that various assumptions about the use phase led to over-whelming deviations in the results for the compared LCA studies. Brandão et al. (2012) calls for more meta-analysis of LCA studies in order to inform users of LCA about the effects of methodological alternatives. Nevertheless, the strength of LCA is that it offers a systematic way to comprehensively describe environmental impacts of a product chain, and it can be done with different degrees of detail in technical processes, environmental impacts and geographical distribution.

Several social and economic elements can be part of the LCA methodology. The relative weighting of different environmental impacts can be based on different social or economic values, and each of these methods convey different information about the product system (Baumann and Rydberg, 1994). Also in relation to allocation in LCA, the division of environmental impact among the products can be based on different social or economic values (Azapagic and Clift, 1999). Moreover, economic input-output tables have been explored for data sources, which has led to new types of LCA: IO-LCA (inputoutput LCA) (Hendrickson et al., 2005) and hybrid LCA, which combines standard LCA with IO-LCA (Suh, 2004). While 'ordinary' LCA principally is a methodology for comparing equivalent product systems, the new types of IO-LCA enable other types of study (cf. Tukker and Jansen, 2006), for example, studies that explore the consumption activities that have the most-polluting product flows in society.

Since IO-LCA studies include the impacts of production that is outsourced to developing countries, they have contributed to the debate on the role of consumption and global industry in sustainability (c.f. Hertwich, 2005). For example, Matos and Hall (2007) analysed the applicability of LCA to agricultural biotechnology and a company's attempts to introduce their technology in Brazil. 
Research seeks to further broaden the scope of LCA methodology, from holistic environmental assessment to comprehensive sustainability assessment. If such developments are to become relevant to a wider community, methodological development must become better informed by the social and economic sciences.

\subsection{Connecting to Ecological Economics}

As is well known by Ecological Economics readers, Costanza (1989) defined the concept as addressing the relationships between natural ecosystems and economic systems in the broadest sense, and thus should be seen from a holistic perspective with the goal of "finding a common language and a set of concepts for the analysis of economies and ecosystems" (Faber et al., 1996, pp. 10). Consistent with our above theoretical overview of the sustainable global value chain discourses, ecological economics makes use of various disciplinary inputs and advocates a trans-disciplinary approach which is focused on solving the problems of modern societies and their ecological impact, and thus has an inherently broad scope. We have thus suggested in this paper that ecological economics is a useful lens to analyze and understand the sustainable development of production and consumption activities. However, to date there have been relatively few papers published in Ecological Economics on this topic (see Table on bibliometrics), an oversight that we wish to rectify with this special subsection.

Of the Ecological Economics papers focused on sustainability within supply chains, few draw on the literature discussed above. For example, Cadarso et al. (2010), Foran et al. (2005) and Lenzen and Murray (2010) draw on input-output theory, the study by Wiedmann et al. (2011) focused on multi-region input-output for global sustainability analyses, and Li et al. (2009) draw on the concept of 'strategic performance measurement system' developed within the field of accounting for understanding ecological performance measures. Drawing on relatively standard economic analysis techniques, Muradian et al. (2002) develops indicators of inter-country environmental load displacement and Kandelaars and van den Bergh (1997) develop a dynamic materials-product chain model based on a dynamic representation of product and materials flows and linkages to various environmental pressure indicators for scenario analysis. While the study by Erol et al. (2011) draws on some of the sustainable supply chain discourse for definitions (such as Carter and Rogers, 2008 and Seuring and Müller, 2008), the theoretical framework builds on the fuzzy entropy method, rather than on theoretical concepts outlined in the sustainable supply chain discourse discussed above.

Papers that are more aligned with the above theoretical discourse include Gerbens-Leenes et al. (2003) analysis of the methods used to improve environmentally sustainable food production, as does Boons and Wagner's (2009) study, although supply chains are only one of three topics in their more general assessment of the relationship between economic and ecological performance. Rieple and Singh's (2010) study of the organic cotton value chain draws on the value and commodity chain analysis discussed above.

Our point here is that, while the topic of sustainable supply/global value chain discourse fits well within Ecological Economics' emphasis on trans-disciplinary and problem-focused research, much of the theoretical discourse has been published elsewhere, and there has been relatively little overlap with such studies and those published within Ecological Economics. Thus, while sustainable product chains are worthy of study, the discourse is currently highly fragmented, resulting a lack of a common theoretical language and set of concepts for analysis. We of course do not see this as a deficiency in the individual studies, but rather acknowledge the need to look at sustainable product chains through different theoretical frameworks, as well as opportunities whereby different theoretical lenses can be applied for fruitful research in the future.

\section{Core Questions to Advance a Holistic Perspective}

Based on the above discussion, we now pose the following questions that could provide a research agenda with a holistic approach to analysing sustainable development and global supply chains.

I. How are sustainability practices diffused through global product chains?

Although many studies have focused on the diffusion of more sustainable practices through global product chains, there remains uncertainty as to how this occurs, and specifically why there is considerable heterogeneity between and within industries. For example, we speculate that more sustainable practices in food commodity chains have become established in fair trade coffee and sustainable seafood, but less so in rice, soybeans or cotton; in extraction-based industries, oil and gas have received more attention for being the cause of 'resource curse' problems than mining. There are also considerable differences within the same industry. For example, US-based Walmart's recent sustainable supply chain programs emerged at least a decade after similar initiatives by European supermarkets such as Sainsbury's and Ahold. National characteristics may also shape these differences. For example Hall (2000) found that UK-based supermarkets were heavily engaged in sustainable supply chain initiatives, whereas Japanese supermarkets were not. There are also knowledge asymmetries within the value chain, for example highly educated professionals that work within larger channel leader firms vs. illiterate subsistence farmers from poor regions (Hall et al., 2009).

Such heterogeneity within the sustainability of global supply chains offers a number of research opportunities worthy of (inter- and trans-disciplinary) theoretical exploration. For example, organization theory might provide insights on whether institutionalization pressures create greater standardization within and among industries, trigger innovative practices or hinder their diffusion. Theories from strategic management and marketing can provide insights on whether firms can position themselves favorably against competition through more effective sustainable supply chain management, whereas the international business discourse can provide insights on how international characteristics shape policies towards global supply chain practices. Sociology can provide insights on how less educated producers from poor regions can participate in more sustainable supply chains. Note that we suggest that drawing on multiple theoretical perspectives such as these would contribute towards our understanding of how sustainable practices diffuse through global product chains.

Several papers in this special subsection begin to develop a more trans-disciplinary perspective along these lines. Manning et al. (2012) link institutional theory to a co-evolutionary perspective on the way in which a variety of sustainability standards persists over time in the global coffee product chain. Zhu and Sarkis (2012) look at relative importance of domestic and international pressure on the extent to which Chinese firms adopt sustainability practices. In their quantitative analysis of the diffusion of lead-free soldering among Chinese suppliers of ICT firms, Tong et al. (2012) include a number of factors from economic geography.

II. Power relationships in product chains: Who is driving the sustainability agenda?

Another area worthy of investigation is the detailed exploration of key actors driving the sustainability agenda in product chains. This includes studies regarding power relations within the product chain, covering governments, NGOs, local communities and other secondary stakeholders that may affect, or be affected, by the product chains. 
Although power relations within product chains have been a rich area of research, it remains a relatively fragmented discourse. We suggest that it would be fruitful to explore how the various concepts of 'power' in the literatures, such as channel power from marketing, profit divisions from the industrial organizational literature, sources of power from social psychology, and stakeholder and dependency theory from organizational theory can inform researchers and practitioners about who sets the agenda. Something that remains crucial but is so far largely unexplored is the relationship between power and legitimization processes, specifically how sustainability issues emerge, become accepted and diffused within supply chains. In this special subsection, the issue of power is dealt with mainly by analysing the role of various actors in inducing the adoption of sustainability practices by firms, as in the studies by Tong et al. (2012) and Zhu and Sarkis (2012). The analysis of the clothing industry provided by Søgaard Jørgensen and Jensen (2012) provides insights into the ways in which sustainability becomes defined and shaped into practices within firms as they interpret various developments in their product chain.

III. Forging change in product chains: How to coordinate for increased sustainability?

Much of the research on sustainability and product chains is at least inspired by the aim to improve sustainability of product chains. The main challenge is the dispersed geographical and institutional nature of product chains: they cross national boundaries and thus link actors together from radically distinct contexts, lacking the option to engage in face-to-face interaction. As a result, any aim that is not served by pure market exchanges faces coordination challenges for the actions of this variety of actors.

Here, perspectives from management science and governance studies can be fruitfully combined into studies that seek to analyse how involved actors coordinate their production and consumption activities as well as their efforts to monitor, regulate, and develop and disseminate knowledge. While management scholars focus on firms and acknowledge that stakeholders need to be involved, governance studies show how effective programs for diffusing sustainability practices often emerge as a result of private initiatives. This indicates that there is a middle ground where these disciplines can fruitfully be combined. In this special subsection, Kogg and Mont (2012 this issue) propose a way of combining the management and governance perspectives, while Vermeulen and Kok (2012) develop a governance perspective based on the analysis of a number of successful cases that addresses the interplay between private and public actors.

IV. How to measure value creation and destruction in global product chains?

The matter of quantitatively measuring the sustainability of product chains is a very large area for research that encompasses economic, ecologic, environmental, social metrics for different types of uses, their relative value and the ways in which they can be combined in meaningful ways. So far, there is no comprehensive framework for this, except for a review sustainability metrics by Clift (2003). Many of the metrics tend to focus on environmental degradation, and only a few methods focus on value creation, e.g. ecosystem services accounting (Mäler et al. 2008) and ecohealth indicators (Rapport 2007). A good sustainability measurement method should be able to measure both, destruction from pollution, resources loss, etc. as well as value creation trough ecological restoration and social development. Attempts to develop more comprehensive and integrated methodologies are on-going in various circles (e.g. the LCSA section of the International Society for Industrial Ecology (ISIE, 2012), sustainability science), but interaction is limited and partly hampered by different vocabularies.

The topic of designing metrics is a compounded one. Environmental problems are multi-dimensional, where the relative significance of different environmental problems has to somehow be determined. Because of this, even a single environmental metric in LCA can be built up by different combinations of ecologic, economic and social measurements, where each combination conveys different information, e.g. distance to environmental policy target, or in relation to cultural values (cf. Baumann and Rydberg, 1994; Baumann and Tillman, 2004). When environmental and economic metrics are combined, then both metrics may contain economic information, but of a different kind. Such issues need analysis for the appropriate interpretation of metrics, with the ensuing analysis focused on different meanings of 'value' in all these metrics of sustainability. Comparative studies of what constitute environmental efficiency (eco-efficiency) and economic efficiency could illustrate the issue at hand.

In addition to the metrics themselves, the uses of product chain sustainability measurements need better understanding for the sake of methodology development-sustainability assessment in the context of a firm's accounting would differ from sustainability assessment for a national economy. Such developments are for example made by a GRI working group to produce sustainable supply chain metrics for corporate sustainability reporting, and projects that aim for description of climate change impacts of a national economy so that also exported and imported impacts are included. However, to go from 'merely' describing climate change impact to comprehensively describing environmental and sustainability issues requires much work into the methods of achieving balanced evaluations. In this special subsection, Brouillat and Oltra (2012) test agent-based modeling to analyse the way in which policy measures affect choices in the Eco-design process.

Elements for an integrated sustainability methodology do exist: the environmental assessment in the form of LCA, economic assessments in the form of life cycle costing (Gluch and Baumann, 2004; Steen, 2005) economic material-product chain models (Schwarz, 2006), social assessment in the form of social LCA (UNEP, 2009) and commodity chain analysis (Gereffi and Korzeniewicz, 1994). Moreover, some combinations have also been tested. In this special subsection, Cadarso et al. (2012) begin to address such issues by developing a criterion for $\mathrm{CO} 2$ emissions that takes international linkages into account. Binder et al. (2012) present a methodology combining ecological impact and socio-economic data, and apply it to the Swiss milk product chain. Many other combinations remain to be tested and evaluated.

Connecting the further refinement and combination of quantitative measures with insights from organization and management science brings into focus that such metrics are part of a broader social process in which actors define the value of a product. While the social construction of value is inherent in the economic process, it becomes visible in particular when ecological and social impact are at issue (Koponen, 2002). In addressing sustainability issues, actors contest current definitions of value; firms that market sustainable innovations put forward an alternative value proposition.

V. Interdisciplinary unification of theories?

The fragmentation from which this paper takes its starting point is related to the specialization in academia, which has led to multiple disciplines and fields of research. Academic specialization, on the one hand, has something to do with differing perspectives on what matters and is interesting. Findings from a fragmented field can provide further understanding through meticulous comparative analysis of underlying assumptions and interdisciplinary translation. Such analysis can uncover 
the complementarity of findings, and can in turn provide a path towards a more unified vocabulary for the field of sustainable product chain study. However, complementarity is not a matter of course. Ontological and epistemological positions can sometimes be opposite in two fields. Whether an action has any element of free will or is wholly decided by social norms, structures etc. are partly mutually exclusive positions, and have been topics for intense debates in academia. Such incommensurability makes comparison of research findings less straight-forward.

Differing knowledge perspectives can be found among the different theoretical 'lenses' presented in Section 2. Whereas the flow modeling methods of environmental engineering firmly rest in a system-based epistemology, sociological research is epistemologically more varied. Economic research originated from a mechanical, reductionist perspective (Mirowski, 1989) but has by now developed into several branches, ranging from mainstream to heterodox economics. Such epistemological differences can prove difficult to reconcile, for example when it comes to what counts as valid indicators, or to what extent similar indicators complement, overlap, or perhaps even contradict each other. The differences among climate change indicators used, for example, in LCA, economics, commodity chain studies need to be assessed in relation to their respective rationales, to provide a more holistic understanding of what climate change constitutes.

Bunge (2011) describes two unification strategies for science. The first is meta-analyses aiming at integrative theoretical understanding, which could be achieved through comparison of research findings, methods and theories used. The other possibility is to achieve synthesis via more open analysis of problems and phenomena. The academic debate for reducing fragmentation is certainly not over. This paper, and the special subsection to which it provides an introduction, hopefully represent a constructive effort towards better trans-disciplinary understanding of sustainability issues for product chains. In order to develop a more holistic understanding of the dynamics in social-ecological systems, dialogue about basic principles of scientific inquiry is a necessary condition. Here, assistance can be sought from scholars who re-open the debate on the basis of ecological economics (e.g. Spash, 2012).

\section{Conclusion}

Current overexploitation of resources, disturbance of ecological cycles, and disposal of waste in ecosystems requires solutions that build on an transdisciplinary understanding of product chains. Ecological economics facilitates such an understanding by addressing the relationships between natural ecosystems and economic systems in the broadest sense (Costanza, 1989). As indicated by the concept of social-ecological systems (Holling, 2001), it adopts a systemic perspective, which includes the feedback loops between economic activities and flows, and ecological processes. The extent to which economic activities stay within the capacity of earth's ecosystem is a major focus of analysis, in terms of resource extraction, the ultimate deposit of wastes, and the interference with ecological cycles at the local, regional and global level (Commoner 1971).

The product chain is one possible unit of analysis that can be adopted by practitioners and researchers to assess the interplay between economic and ecological dynamics (Boons and Wagner, 2009). The questions presented above serve as a way to address, within that system boundary, three major focal areas of ecological economics as defined by for instance Faber et al. (1996).

A first area concerns the measurement of the way in which economic activities affect ecological systems, and the incorporation of such measures in definitions of economic growth. Such incorporation is deemed necessary to make it part of the decision making of economic actors and policymakers. One of the advantages of the product chain system boundary is that it combines a meaningful measurement of such ecological impact (i.e. the ability to take into account substitution and rebound effects) with an arena where actors have at least in some important cases proven to be able to coordinate and govern their actions. This combination of assessment and governance needs to be further analyzed for its possibilities for diffusion.

A second issue is constituted by the normative dimension of sustainability. Any definition of sustainability is necessarily value dependent, as will the activities motivated by that definition. This requires careful consideration of the value positions behind actions, as well as the way in which collective arrangements (organized by private actors, governments, and/or NGOs) are sensitive to such differences. The work on commodity chains has revealed how dependencies give unequal room for actors in different parts of the product chain; as a consequence, definitions of sustainability are affected by the dynamics generated by asymmetric dependencies (Boons and Mendoza, 2010).

A third focal area is to develop analytical tools for studying the interplay between economic and ecological dynamics. The study of sustainability of product chains is inherently interdisciplinary, as it combines the environmental science of measuring impacts with the various disciplines that study the socio-economic system at the firm and societal level. One of the aims for this special subsection has been to bring the insights of these fields together, to provide a basis for developing new analytical tools.

\section{References}

Ailawadi, K.L., Borin, N., Farris, P., 1995. Market power and performance: a cross-industry analysis of manufacturers and retailers. Journal of Marketing 71 (3), 211-248.

Aldrich, H., Fiol, M., 1994. Fools rush in? The institutional context of industry creation. Academy of Management Review 19, 645-670.

Aurich, J.C., Fuchs, C., DeVries, M.F., 2004. An approach to life cycle oriented technical service design. CIRP Annals 53 (1), 151-154 C.

Azapagic, A., Clift, R., 1999. Allocation of environmental burdens in multiple-function systems. Journal of Cleaner Production 7 (2), 101-119.

Bansal, P., Gao, J., 2006. Building the future by looking to the past. Examining Research Published on Organizations and Environment. Organization and Environment 19 (4), 458-478.

Bateson, G., 1972. Steps towards an ecology of mind. Ballantine Books, New York.

Baumann, H., Rydberg, T., 1994. Life cycle assessment: a comparison of three methods for impact analysis and evaluation. Journal of Cleaner Production 2 (1), 13-20.

Baumann, H., Tillman, A.M., 2004. The Hitch Hiker's Guide to LCA. An orientation in life cycle assessment methodology and application. Studentlitteratur, Lund, Sweden.

Baumol, W.J., 1990. Entrepreneurship: productive, unproductive, and destructive. Journal of Political Economy 98, 893-921.

Binder, C., Schmid, A., Steinberger, J., 2012. Sustainability Solution Space of the Swiss Milk value added chain. Ecological Economics.

Boons, F., 2009. Creating ecological value. An evolutionary approach to business firms and the natural environment. Edward Elgar, Cheltenham.

Boons, F., Wagner, M., 2009. Assessing the relationship between economic and ecological performance: distinguishing system levels and the role of innovation. Ecological Economics 68, 1908-1914.

Boons, F., Mendoza, A., 2010. Constructing sustainable palm oil: how actors define sustainability. Journal of Cleaner Production 18 (16-17), 1686-1695.

Boons, F.A., 2002. Greening products: a framework for product chain management. Journal of Cleaner Production 10 (5), 495-506.

Brandão, M., Heath, G., Cooper, J., 2012. What can meta-analyses tell us about the reliability of life cycle assessment for decision support? Journal of Industrial Ecology 16 (Suppl. 1), S3-S7.

Brouillat, E., Oltra, V., 2012. Extended producer responsibility instruments and innovation in eco-design: an exploration through a simulation model. Ecological Economics.

Brunklaus, B., Thormark, C., Baumann, H., 2010. Illustrating limitations of energy studies of buildings with LCA and actor analysis. Building research and Information 38 (3), 265-279.

Bunge, M., 2011. Two unification strategies: Analysis or reduction, and synthesis or integration. In: Symons, J., et al. (Ed.), Otto Neurath and the Unity of Science: Logic, Epistemology and the Unity of Science, 18, pp. 145-157 (part II).

Cadarso, M.-A., López, L.-E., Gómez, N., Tobarra, MO.A., 2010. CO2 emissions of international freight transport and offshoring: measurement and allocation. Ecological Economics 69 (2010), 1682-1694

Cadarso, M., Gómez, N., López, L., Tobarra, M., 2012. International Trade and Shared Environmental Responsibility by Sector. An Application to the Spanish Economy. Ecological Economics. 
Carter, C., Rogers, D., 2008. A framework of sustainable supply chain management: moving toward new theory. International Journal of Physical Distribution and Logistics Management 38 (5), 360-387.

Cave, L., Blomquist, G., 2008. Environmental policy in the European Union: Fostering the development of pollution havens? Ecological Economics 65, 253-261.

Coase, R., 1937. The nature of the firm", Origins (1937). In: Williamson, O., Winter, S. (Eds.), The nature of the firm", Origins, Evolution, and Development. Oxford University Press, Oxford. 1993).

Commoner, B., 1971. The Closing Circle: Nature, Man, and Technology. Knopf, New York

Connelly, B., Ketchen, D., Slater, S., 2011. Toward a "theoretical toolbox" for sustainability research in marketing. Journal of the Academy of Marketing Science 39, 86-100.

Costanza, R., 1989. What is ecological economics? Ecological Economics 1, 1-7.

Dahlström, K., Ekins, P., 2006. Combining economic and environmental dimensions: Value chain analysis of UK iron and steel flows. Ecological Economics 58 (3), 507-519.

Delmas, M., Montiel, I., 2009. Greening the supply chain: when is customer pressure effective? Journal of Economics and Management Strategy 18 (1), 171-201.

Deutz, P., Gibbs, D., 2008. Industrial ecology and regional development: Eco-industrial development as cluster policy. Regional Studies 42 (10), 1313-1328.

Dicken, P., 1994. Global-local tensions: firms and states in the global space-economy. Economic Geography 70 (2), 101-128.

DiMaggio, P., Powell, W., 1983. The iron cage revisited: institutional isomorphism and collective rationality in organisational fields. American Sociological Review 48, $147-160$.

Dowling, J., Pfeffer, J., 1975. Organizational legitimation. The Pacific Sociological Review 18 (1), 122-136.

Ekvall, T., 1992. Life-cycle analyses of corrugated cardboard. A Comparative Analysis of Two Existing Studies. Chalmers industriteknik, Göteborg, Sweden.

Ekvall, T., 1999. Key methodological issues for lifecycle inventory analysis of paper recycling. Journal of Cleaner Production 7 (4), 281-294.

El-Ansary, A., Stern, L., 1972. Power measurement in the distribution channel (1972) Journal of Marketing Research 9, 47-52 (February):

Erol, I., Sencer, S., Saris, R., 2011. A new fuzzy multi-criteria framework for measuring sustainability performance of a supply chain. Ecological Economics 70 (2011), 1088-1100.

Evan, W., 1966. The organization-set: toward a theory of interorganizational relations In: Thompson, J. (Ed.), Approaches to organizational design. University of Pittsburgh Press, Pittsburgh, pp. 175-191.

Faber, M., Manstetten, R., Proops, J.L.R., 1996. Ecological Economics: Concepts and Methods. Edward Elgar, Cheltenham. (Foran et al (2005)).

Foran, B., Lenzen, M., Dey, C., Bilek, M., 2005. Integrating sustainable chain management with triple bottom line accounting. Ecological Economics 52 (2), 143-157.

Frankl, P., Rubik, F. (Eds.), 2000. Life Cycle Assessment in Industry and Business: Adoption Patterns, Applications and Implications. Springer Verlag, Berlin, Germany.

French, J., Raven, B., 1959. The bases of social power. In: Cartwright, D. (Ed.), Studies in Social Power. University of Michigan, Ann Arbor.

Gellert, P., 2003. Renegotiating a timber commodity chain: lessons from Indonesia on the political construction of commodity chains. Sociological Forum 18 (1), 53-84.

Gerbens-Leenes, P.W., Moll, H.C., Schoot Uiterkamp, A.J.M., 2003. Design and development of a measuring method for environmental sustainability in food production systems. Ecological Economics 46 (2003), 231-248.

Gereffi, G., 1999. International trade and industrial upgrading in the apparel commodity chain. Journal of International Economics 48, 37-70.

Gereffi, G., 2001. Shifting governance structures in global product chains, with special reference to the Internet. American Behavioral Scientist 44 (10), 1616-1637.

Gereffi, G., Korzeniewicz, M. (Eds.), 1994. Commodity Chains and Global Capitalism. Praeger, Westport (CT).

Gereffi, G., Humphrey, J., Sturgeon, T., 2005. The governance of global value chains. Review of International Political Economy 12 (1), 78-104.

Giuliani, E., Bell, M., 2005. The micro-determinants of meso-level learning and innovation. Evidence from a Chilean wine cluster'. Research Policy 34, 47-68.

Giuliani, E., Pietrobelli, C., Rabellotti, R., 2005. Upgrading in global value chains: lessons from Latin American clusters. World Development 33, 549-573.

Gluch, P., Baumann, H., 2004. The life cycle costing (LCC) approach: a conceptual discussion of its usefulness for environmental decision-making. Building and Environment 39 (5), 571-580.

Goldbach, M., Seuring, S., Back, S., 2003. Co-ordinating sustainable cotton chains for the mass market. Greener Management International 43, 65-78.

Green, K., Morton, B., New, S., 2000. Greening organizations: Purchasing, consumption, and innovation. Organization and Environment 13 (2), 206-225.

Guinée, J.B. (Ed.), 2002. Handbook on life cycle assessment operational guide to the ISO standards. Kluwer Academic Publishers, Dordrecht, NL

Harland, C., 1996. Supply Chain Management: relationships, chains and networks. British Journal of Management 7, 63-80 (Special Issue).

Hall, J., 2000. Environmental supply chain dynamics. Journal of Cleaner Production 8, $455-471$.

Hall, J., 2001. Environmental supply-chain innovation. Greener Management International 35, 105-119.

Hall, J., Matos, S., 2010. Incorporating impoverished communities in sustainable supply chains. International Journal of Physical Distribution and Logistics Management 40, 124-147.

Hall, J., Matos, S., Severino, L., Beltrao, N., 2009. Brazilian biofuels and social exclusion: established and concentrated ethanol vs. emerging and dispersed bio-diesel. Journal of Cleaner Production 17, S77-S85 (supplement 1).

Hall, J., Matos, M., Silvestre, B., Martin, M., 2011. Managing the technological, commercial, organizational and social uncertainties of industrial evolution. The Case of
Brazilian Energy and Agriculture, Technological Forecasting and Social Change, 78, pp. 1147-1157.

Hall, J., Matos, S., Sheehan, L., Silvestre, B., 2012. Entrepreneurship and innovation at the base of the pyramid: a recipe for inclusive growth or social exclusion. Journal of Management Studies. http://dx.doi.org/10.1111/j.1467-6486.2012.01044.x.

Hendrickson, C.T., Lave, L.B., Matthews, H.S., 2005. Environmental Life Cycle Assessment of Goods and Services: An Input-Output Approach. RFF Press, Washington DC US.

Hertwich, E.G., 2005. Life cycle approaches to sustainable consumption: a critical review. Environmental Science \& Technology 39 (13), 4673-4684.

Hoffman, A., 1997. From heresy to dogma. The New Lexington Press, San Francisco.

Holling, C.S., 2001. Understanding the complexity of economic, ecological, and social systems. Ecosystems 4, 390-405.

Hopkins, T., Wallerstein, I., 1977. Patterns of development of the modern worldsystem. Review 1 (2), 128 11-145.

Humphrey, J., Schmitz, H., 2002. How does insertion in global value chains affect upgrading industrial clusters? Regional Studies 36, 1017-1027 (Kaplinsky 2000).

Hunt, R.G., Franklin, W.E., 1996. LCA-how it came about. Personal reflections on the origin and the development of LCA in the USA. The international journal of life cycle assessment (1), 4-7.

Iansiti, M., Levien, R., 2004. Strategy as ecology. Harvard Business Review 69-78 (March).

ISIE, 2012. LCSA (Life Cycle Sustainability Assessment. Topical section of the International Society for Industrial Ecology (http://is4ie.org/topicalsections (accessed May 9, 2012).).

Kandelaars, P., van den Bergh, J., 1997. Dynamic analysis of materials-product chains an application to window frames. Ecological Economics 22 (1), 41-61.

Kaplinsky, R., 2000. Globalisation and Unequalisation: What Can Be Learned from Value Chain Analysis? Journal of Development Studies 37 (2), 117-146.

Kirzner, I., 1973. Competition and Entrepreneurship. University of Chicago Press Chicago, IL.

Kogg, B., Mont, O., 2012. Environmental and social responsibility in supply chains: the practice of choice and/or interorganisational management. Ecological Economics.

Kolk, A., 2005. Corporate social responsibility in the coffee sector: the dynamics of MNC responses and code development. European Management Journal 23 (2), 228-236.

Koponen, T., 2002. Commodities in action: measuring embeddedness and imposing values. The Sociological Review 50 (4), 543-569.

Kuhn, T., 1962. The Structure of Scientific Revolutions. University of Chicago Press, Chicago.

Langer, E., 1989. Minding matters: the consequences of mindlessness-mindfulness. In: Berkowitz, L. (Ed.), Advances in Experimental Social Psychology, Vol. 22. Academic, San Diego, CA, pp. 137-173.

Lenzen, M., Murray, J., 2010. (2010) Conceptualising environmental responsibility. Ecological Economics 70, 261-270.

Li, X., Gu, X., Liu, Z., 2009. A strategic performance measurement system for firms across supply and demand chains on the analogy of ecological succession. Ecological Economics 68 (12), 2918-2929.

London, T., Hart, S.L., 2004. Reinventing strategies for emerging markets: beyond the transnational model. Journal of International Business Studies 35, 350-370.

Lozanoa, J., Blancob, E., Rey-Maquieiraa, J., 2010. Can ecolabels survive in the long run? The role of initial conditions. Ecological Economics 69 (12), 2525-2534.

Mäler, K., Aniyar, S., Jansson, A., 2008. Accounting for ecosystem services as a way to understand the requirements for sustainable development. Proceedings of the $\mathrm{Na}-$ tional Academy of Sciences 105, 9501-9506.

Manning, S., Boons, F.A., Von Hagen, O., Reinecke, J., 2012. National contexts matter: The co-evolution of sustainability standards in global value chains. Ecological Economics 83, 197-209 (this issue).

Matos, S., Hall, J., 2007. Integrating Sustainable Development in the Extended Value Chain: The Case of Life Cycle Assessment in the Oil \& Gas and Agricultural Biotechnology Industries. Journal of Operations Management 25, 1083-1102.

Matsuhashi, R., Kudoh, Y., Yoshida, Y., Ishitani, H., Yoshioka, M., Yoshioka, K., 2000. Life cycle of CO 2-emissions from electric vehicles and gasoline vehicles utilizing a process-relational model. The international journal of life cycle assessment 5 (5), 306-312.

Meisner Rosen, C., Bercovitz, J., Beckman, S., 2000. Environmental supply-chain management in the computer industry: a transaction cost economics perspective. Journal of Industrial Ecology 4 (4), 83-103.

Mirowski, P., 1989. More Heat than Light. Cambridge University Press, Cambridge.

Moore, J., 1993. Predators and prey: A new ecology of competition. Harvard Business Review 75-86 (May-June)

Morrison, A., Pietrobelli, C., Rabellotti, R., 2008. Global value chains and technological capabilities: a framework to study learning and innovation in developing countries. Oxford Development Studies 36, 39-58.

Muradian, R., O'Connor, M., Martinez-Alier, J., 2002. Embodied pollution in trade: estimating the 'environmental load displacement' of industrialised countries. Ecological Economics 41 (1), 51-67.

Nelson, R., Winter, S., 1982. An Evolutionary Theory of Economic Change. Harvard University Press, Cambridge, MA.

Oliver, C., 1991. Strategic responses to institutional processes. Academy of Management Review 16 (1), 145-179.

Oltra, V., Saint-Jean, M., 2009. Sectoral systems of environmental innovation: An application to the French automotive industry. Technological Forecasting and Social Change 76 (4), 567-583. 
Pfeffer, J., Salancik, G., 1978. The external control of organizations. A resource dependency perspective. Harper \& Row, New York.

Popper, K., 1945. The Open Society and its Enemies. Routledge, London.

Popper, K., 1959. Conjectures and Refutations, 5th ed. Harper and Row, New York.

Porter, M.E., 1980. Competitive Strategy. The Free Press, New York, NY.

Porter, M.E., Kramer, M.R., 2006. Strategy and society: the link between competitive advantage and corporate social responsibility. Harvard Business Review 84 (12), 78-92.

Prahalad, C., 2007. The Fortune at the Bottom of the Pyramid: Eradicating Poverty through Profits. Pearson Educational/Wharton School Publishing, Upper Saddle River, NJ. ().

Price, R., 1995. Effects of channel leadership behaviors under different levels of channel member interdependence. Journal of Retailing 71, 261-278.

Ramachandran, J., Pant, A., Kumar Pani, S., 2012. Building the BoP Producer Ecosystem: The Evolving Engagement of Fabindia with Indian Handloom Artisans. Journal of Product Innovation Management 29 (1), 33-51.

Rapport, D.J., 2007. Sustainability science: an ecohealth perspective. Sustainability Science 2 (1), 77-84

Rieple, A., Singh, R., 2010. A value chain analysis of the organic cotton industry: the case of UK retailers and Indian suppliers. Ecological Economics 69, 2292-2302.

Rowley, T., 1997. Moving Beyond Dyadic Ties: A Network Theory of Stakeholder Influences. Academy of Management Review 22 (4), 887-911.

Rubik, F., 2006. Policy profile: integrated product policy-between conceptual and instrumental approaches in Europe. European Environment 16 (5), 307-320.

Schouten, G., Glasbergen, P., 2011. Creating legitimacy in global private governance: the case of the roundtable on sustainable palm oil. Ecological Economics 70 (11), 1891-1899.

Schwarz, H.G., 2006. Economic materials-product chain models: current status, further development and an illustrative example. Ecological Economics 58 (2), 373-392.

SETAC, 1993. Guidelines for Life-cycle Assessment: A ‘Code of Practice’: Society of Environmental Toxicology and Chemistry, Brussels, Belgium \& Pensacola, FL, USA

Seuring, S., Müller, M., 2008. From a literature review to a conceptual framework for sustainable supply chain management. Journal of Cleaner Production 16, 1699-1710.

Søgaard Jørgensen, M., Jensen, C., 2012. The shaping of environmental impacts from Danish production and consumption of clothing. Ecological Economics.

Spaargaren, G., 2003. Sustainable Consumption: A Theoretical and Environmental Policy Perspective. Society and Natural Resources 16, 687-701.
Spash, C.L., 2012. New foundations for ecological economics. Ecological Economics 77, 36-47 (May 2012).

Steen, B., 2005. Environmental costs and benefits in life cycle costing. Management of Environmental Quality: An International Journal 16 (2), 107-118.

Stinchcombe, A., 1968. Constructing social theories. University of Chicago Press, Chicago.

Suchman, M., 1995. Managing legitimacy: strategic and institutional approaches. Academy of Management Review 20 (3), 571-610.

Suh, S., 2004. Functions, commodities and environmental impacts in an ecological-economic model. Ecological Economics 48 (4), 451-467.

Tate, W., Dooley, K., Ellram, L., 2011. Transaction cost and institutional drivers of supplier adoption of environmental practices. Journal of Business Logistics 32 (1), 6-16.

Teehan, P., Kandlikar, M., 2012. Sources of variation in life cycle assessments of desktop computers. Journal of Industrial Ecology 16 (Suppl. 1), S182-S194.

Tong, X., Shi, J., Zhou, Y., 2012. Greening of supply chain in Developing Countries: Diffusion of $\operatorname{Lead}(\mathrm{Pb})$-free Soldering in ICT Manufacturers in China. Ecological Economics.

Toulmin, S., 1972. Human understanding. Princeton University Press, Princeton.

Tukker, A., Jansen, B., 2006. Environmental impacts of products: a detailed review of studies. Journal of Industrial Ecology 10 (3), 159-182.

UNEP, 2009. Guidelines for social life cycle assessment. The UNEP-SETAC LCInitiative, United Nations Environmental Programme, Paris, France.

Vermeulen, W., Kok, M., 2012. Government Interventions in Sustainable Supply Chain Governance: Experience in Dutch front running Cases. Ecological Economics.

Weber, M., Hemmelskamp, J. (Eds.), 2005. Towards environmental innovation systems. Springer, Berlin.

Wickson, F., Carell, A., Russell, A., 2006. Transdisciplinary research: characteristics, quandaries and quality. Futures 38 (9), 1046-1059.

Wiedmann, T. Wilting, H., Lenzen, M., Lutter, S., Palm, V., 2011. Quo vadis MRIO? Methodological, data and institutional requirements for multi-region input-output analysis. Ecological Economics 70, 1937-1945.

Williamson, O., 1985. Transaction Cost Economics: The Governance of Contractual Arrangements. Free Press, New York.

Williamson, O.E., 1975. Markets and Hierarchies: Analysis and Antitrust Implications. Free, New York.

Zhu, Q., Sarkis, J., 2012. International and Domestic Pressures and Responses of Chinese Firms to Greening. Ecological Economics. 